\title{
Effect of Wheat Grains Soaking in Micro-element Solutions on Yield and its Components
}

Nadia M. Mahmoud ; E.A. Teama ; A.M. Abou-Salama and Anaam H. Galal

${ }^{1}$ Agronomy Department, Faculty of Agriculture, Assiut University

\section{Abstract:}

This investigation was carried out in the Agricultural Experimental Farm at Fac. Agric., Assiut Univ., during the two winter growing seasons 2009/2010 and 2010/2011 to study the effect of wheat grains soaking in micro-element solutions on yield and its components. The used experimental design was a Randomized Complete Block Design in split-plot with four replications. Wheat varieties (Giza 168 and Bani-Swef 1) were allocated in the main plot, while micronutrient treatments $(\mathrm{Fe}, \mathrm{Zn}, \mathrm{Mn}, \mathrm{Fe}+\mathrm{Mn}, \mathrm{Zn}+\mathrm{Mn}, \mathrm{Fe}+\mathrm{Zn}$ and $\mathrm{Fe}+\mathrm{Mn}+\mathrm{Zn})$ were distributed in the sup-plot. The plot area was $3 \times 3.5 \mathrm{~m}^{2}$. The results could be summarized as follows:

- Giza 168 variety surpassed and gave significant increase in the spike length, 1000-grains weight and straw yield in both season, as well as in the first season only gave significant increase in number of spikelets/spike and number of spike/m² over Bani-Swef 1.

- The maximum values for plant height, spike length, 1000-grains weight, number of spikelets/spike, number of spikes $/ \mathrm{m}^{2}$, grain yield/fed., straw yield/fed. were recorded by $\mathrm{Fe}+\mathrm{Mn}+\mathrm{Zn}$ treatment in both seasons.

- The interaction between varieties and micronutrient treatments had nonsignificant effect on the all studied traits in both seasons.

Keywords: Soaking, micro-element, solution.

\begin{tabular}{lc}
\hline \hline Received on: $16 / 11 / 2014$ & Accepted for publication on: 30/11/2014 \\
Referees: Prof. Ragab A. E. Dawood $\quad$ Prof. Eman M. Taha
\end{tabular}




\section{Introduction:}

In Egypt, wheat has been considered to be the first strategic cereal crop for making bread as well as the wheat straw is important for hay feeding. Therefore, it is the first food crop in Egypt and the whole world. Wheat occupied an area estimated at about 3.6 million fed. with total production 8.28 million ton with average grain yield 18.00 ardab/fed. (FAO, 2013). However, this production did not meet consumption party due to crop leakage for other misused as well as the over growing population and hence consumption.

Zinc is micronutrient required in traces for normal plant growth, zinc plays essential metabolic roles in plant and works as regulatory cofactor for several enzymes. It is very closely involved in $\mathrm{N}$ metabolism of the plant. In levels are markedly zinc deficient plants protein synthesis, protein reduced, and amino acids and amides are accumulated. Iron is involved in the production of chlorophyll and iron chlorosis is easily recognized on iron sensitive crops growing calcareous soils. Iron also a component of many enzymes associated with energy transfer, nitrogen reduction and fixation, and lignin formation. Manganese is necessary in photosynthesis, nitrogen metabolism to form other compounds required for plant metabolism. Few reports examined the effect of grains soaking in micronutrients on maize uptake of nitrogen.

Harb (1992) used seed soaking of faba bean and cotton with micronutrients or growth regulator. He reported that the treatment led to an increase in seed yield. Zhang et al. (1992) reported that seed treatment of maize and rice with zinc sulphate in- creased zinc uptake in both crops. Furthermore, they reported that yield increases in rice due to soaking. Jeyabal and Kuppuswamy (1998), found that seed soaking with zinc along with other organic biofertilizers improved rice seedling characteristics. Nitrogen uptake improved by up to $11.8 \%$ in early seedling age (30 days) growth and yield attributes increased due to seed soaking. Grain yield increased by $8.8 \%$ over unsoaked seeds. Saad et al. (1999) studied small cereal soaking with zinc sulphate; they found that $0.01 \%$ zinc sulphate increased grain yield of wheat, barley and triticale.

Brennan (2001) observed that applied zinc fertilizers increased wheat dry matter, zinc content of the dry matter and grain yields. In nutrient priming, seeds are pretreated (primed) in solutions containing the limiting nutrients instead of being soaking simply in water (Arif et al., 2005). Iron (Fe), zinc ( $\mathrm{Zn})$, manganese $(\mathrm{Mn})$ are essential micronutrients for plant and humans (Kaya et al., 1999; Asad and Rafique, 2000). Hao et al. (2007) reported that a deficiency of just one of these nutrients can greatly reduce plant yield and even cause plant death. Micronutrient deficiency, especially Fe and Zn deficiency, is widespread in humans (Graham et al., 1999; Stoltzfus, 2001 and Liu et al., 2006). Crop management strategies are an important complement to on going breeding programs. Studies have shown that $\mathrm{Fe}, \mathrm{Zn}, \mathrm{Cu}$ and $\mathrm{Mn}$ concentration in rice or wheat grain can be increased by proper irrigation management, $\mathrm{N}$ fertilization, and late planting (Hao et al., 2007 and Pearson et al., 2008). A number of studies have reported that the application of micronutrient ferti- 
lizers to the soil or crop foliage increased micronutrient concentrations in grain. However, some authors found that foliar sprays resulted in nutritional disorders and imbalances (Ghasemi-Fassaei and Ronaghi, 2008; Pahlavan-Rael and Pessarakli, 2009).

The effects of soaking whole cereal (rice, maize, sorghum) and legume seeds (mung bean, cow pea, soybean) on iron $(\mathrm{Fe})$, zinc $(\mathrm{Zn})$ contents were investigated. In all the above cereals, except millet, the molar rations of Phy/Fe were above 20, while, in legumes, ration were lower. Soaking whole seeds for $24 \mathrm{~h}$ led to leaching of iron and to a lesser extent, of zinc ions into the soaking medium. This work aimed to investigate the effect of wheat grains soaking in micro-element solutions on the yield and its components.

\section{Materials and Methods:}

This work was carried out at the Experimental Farm of the Faculty of Agriculture, Assiut University, during the two winter growing seasons 2009/2010 and 2010/2011, to study the effect of wheat grains soaking in micro-element solutions on yield and its components. The soil of the experimental site was clay. The main properties of the soil are given in Table (1).

Table 1: Average of the main properties of the experimental soil in $2009 / 2010$ and $2010 / 2011$ seasons.

\begin{tabular}{|l|c|c|}
\hline \multirow{2}{*}{\multicolumn{1}{c|}{ Soil properties }} & \multicolumn{2}{|c|}{ values } \\
\cline { 2 - 3 } Analysis: & $\mathbf{2 0 0 9 / 2 0 1 0}$ & $\mathbf{2 0 1 0 / 2 0 1 1}$ \\
\hline Sand \% & 26.6 & 27.2 \\
\hline Silt \% & 25.2 & 22.3 \\
\hline Clay \% & 48.8 & 48.4 \\
\hline Texture & Clay & Clay \\
\hline E.C. $(\%)$ & 42.0 & 41.0 \\
\hline Organic matter & 1.80 & 2.0 \\
\hline pH & 7.8 & 7.9 \\
\hline Available P (ppm) & 9.0 & 10.0 \\
\hline Available Fe (ppm) & 129.0 & 128.0 \\
\hline Available Mn (pm) & 24.2 & 25.4 \\
\hline Available Zn (ppm) & 20.7 & 21.8 \\
\hline Total N \% & 0.08 & 0.081 \\
\hline
\end{tabular}

The used experiment design was a Randomized Complete Block Design in split-plot arrangement of treatments with four replications. Wheat varieties (Giza 168 and BaniSwef 1) were allocated in the main plots, while micro-element solutions were randomly distributed in the subplots.

The experiment was planted on the 26 November in both seasons. The area of each plot was $3 \times 3.5 \mathrm{~m}^{2}$ in each season. Wheat grains were soaked for 24 hours before planting in one of the seven different solutions along with a control treatment of distilled water. The solutions contained $100 \mathrm{ppm}$ of either; $\mathrm{MnSO}_{4} \cdot \mathrm{H}_{2} \mathrm{O}$, Fe$\mathrm{SO}_{4} .7 \mathrm{H}_{2} \mathrm{O}, \mathrm{ZnSO}_{4} .7 \mathrm{H}_{2} \mathrm{O}$ as single compound or their combinations of the above micronutrients as two elements mixture for $\mathrm{Fe}$ and $\mathrm{Zn}, \mathrm{Zn}$ and $\mathrm{Mn}$ and $\mathrm{Fe}$ and $\mathrm{Mn}$ as well as three elements mixture for $\mathrm{Fe}, \mathrm{Mn}$ and $\mathrm{Zn}$. 
The seeding rate were 60 $\mathrm{kg} / \mathrm{fed}$. in Giza 168 and $70 \mathrm{~kg} / \mathrm{fed}$. in Bani-Swef 1. recommended rates of $70 \mathrm{~kg}$ nitrogen was applied as ammonium nitrate $(33.5 \% \mathrm{~N})$ and $31 \mathrm{~kg}$ phosphorus was applied as a single super-phosphate $\left(15.5 \% \mathrm{P}_{2} \mathrm{O}_{5}\right)$ during soil preparation as well as potassium was applied as potassium sulphate $\left(48 \% \mathrm{~K}_{2} \mathrm{O}\right)$.

The characters studied in this respect were:

1- Plant height: at harvest, measured in $\mathrm{cm}$ from surface of the soil to the top of the spike of five main stems.

2- Spike length, $\mathrm{cm}$.

3- Number of spikelets per spike.

4- Number of spikes $/ \mathrm{m}^{2}$.

5- Seed index, i.e. 1000 grain weight, gm.

6- Grain yield ardab/fed.

7- Straw yield in ton/fed.

\section{Statistical analysis:}

The obtained data in each season were statistically analyzed according to procedure outlined by Gomez and Gomez (1984). Means comparison were done using revised least significant differences (RLSD) at $5 \%$ level of probability.

\section{Results and Discussion: Effect of varieties:}

Data in table 2 showed that the spike length, 1000 grains weight and straw yield/fed. in both seasons had a highly significantly as well as the number of spikelets/ spike and number of spikes $/ \mathrm{m}^{2}$ in the $1^{\text {st }}$ season only had a significantly affected by the wheat varieties. On the other hand, the plant height and grain yield/fed. in both season as well as the number of spikelets/spike and number of spikes $/ \mathrm{m}^{2}$ in the $2^{\text {nd }}$ season had nonsignificant affected by the wheat varieties. It is clear that the wheat varie- ty (Giza 168) gave a significant increase in the spike length $(\mathrm{cm}), 1000$ grains weight (gm) and straw yield/fed. (ton) in both seasons as well as in the $1^{\text {st }}$ season only for the number of spikelets/spike and number of spikes $/ \mathrm{m}^{2}$. The results indicated that the wheat variety (BaniSwef 1) gave the lowest values for the all studied traits. Moreover, the tallest plants gave maximum straw yield/fed., as well as the increase of spike length and 1000 grains weight (gm) may be realized increase in the grain yield/fed. This result may be due to the genotypes make up reflecting improvement in yield components. Zaki et al. (2012) reported that Sakha 93 cultivar gave higher number of spikes $/ \mathrm{m}^{2}$ and grain yield (ton/fed.) than Gemmiza in both seasons. Varietal differences in yield components between wheat varieties were in conformity with those obtained by ElHabbal et al. (2000), Hassan and GabAllah (2000), Hossain et al. (2002), Allam et al. (2007), El-Metwally and Saudy (2009) and Noureldin et al. (2013) who reported that a significant differences among the tested wheat cultivars in the two seasons for number of spike $/ \mathrm{m}^{2}$, spike length, kernel number/spike, weight of 1000 kernels and grain and straw yields/fed.

\section{Effect of the seed soaking in micro- nutrient solution:}

The data in table 2 showed that the all studied traits had a highly significant affected by the soaking in micronutrients solution in both seasons. The tallest plants $(99.90$ and $99.03 \mathrm{~cm})$, the tallest spike $(10.58$ and $11.30 \mathrm{~cm})$, the heaviest 1000 grains (48.16 and $50.40 \mathrm{gm}$ ), the highest values of number of 
spikelets/spike (20.13 and 20.86), number of spikes $/ \mathrm{m}^{2}$ (486.9 and 491.8) the maximum grains yield/fed. (19.32 and 18.96 ard.) and the maximum straw yields/fed. (3.97 and 4.37 ton) were recorded by the three elements mixture treatment $(\mathrm{Fe}+\mathrm{Mn}+$ $\mathrm{Zn}$ ) in the $1^{\text {st }}$ and the $2^{\text {nd }}$ seasons, respectively. Moreover, the plants treated with $\mathrm{Fe}+\mathrm{Zn}, \mathrm{Zn}+\mathrm{Mn}$ and $\mathrm{Fe}+\mathrm{Mn}$ treatments had significant increase in all studied traits over the control treatment (unsoaked grains) in both seasons. Generally, all treatments receiving micronutrient: $\mathrm{Fe}, \mathrm{Zn}$ and $\mathrm{Mn}$ either alone or combined together gave the highest values over the control in both seasons. Here, the results emphasized the important role for the trace elements $(\mathrm{Fe}, \mathrm{Zn}$ and $\mathrm{Mn})$ to increase the plant height, yield and yield attributes under this study, as well as showed that the synergetic role of micronutrients in improving plant growth and other biochemical and physiological activities. Brennan (2001) observed that applied zinc fertilizers increased wheat dry weight and grain yield. Similar findings were reported by Teama (2001) who found that the use of a single element for soaking was better than the control. All the two element mixtures were better than single element as well as the three-element mixture was the best of all soaking treatments. Massoud et al. (2004) reported that applying zinc increased grain yield, straw yield and 1000 grain weight. Moreover, zinc is the essential act as a metal-activator for the synthesis of plant growth regulators like auxin, also of several enzymes, involved in the synthesis of protein and nucleic acids in plants. These are in agreement with those reported by Zaki et al. (1992), Saad et al. (1999), Asad and Rafique
(2000), Brennen (2001), Liu et al. (2006), Hao et al. (2007), Pearson et al. (2008), Pahlavan-Rael and Pessarkli (2009) and Salem and ElGizawy (2012) who reported that number of ears/plant, number of grains/ear, 100-grain weight and grain yield increased by applying $\mathrm{Zn}$, $\mathrm{Mn}$ and Fe singly or combined. Such increases were particularly significant by the $\mathrm{Zn}+\mathrm{Mn}+\mathrm{Fe}$ treatment with regard to 100 -grain weight, ear weight and grain yield.

\section{Effect of the interactions:}

The data in table 3 revealed that the all studied traits had nonsignificant affects by the varieties with soaking grains in micronutrient interactions in the both seasons. Although the insignificant effect for all the studied traits by the interactions, the results indicated that the best values $(102.20$ and $100.10 \mathrm{~cm}),(11.7$ and $12.4 \mathrm{~cm}),(21.20$ and 21.83$)$, (546.5 and 551.0), (19.05 and 19.32 $\operatorname{ard} /$ fed.) and (4.34 and 4.73 ton/fed.) were realized by $\mathrm{V} 1 \mathrm{xC} 8$ interaction (Giza 168 variety x soaking grains in $\mathrm{Fe}+\mathrm{Mn}+\mathrm{Zn}$ micronutrients) for the plant height, spike length, number of spikelets/spike, number of spikes $/ \mathrm{m}^{2}$, grain yield/fed. and straw yield/fed. in the $1^{\text {st }}$ and the $2^{\text {nd }}$ seasons, respectively. The lowest values (88.75 and $89.00 \mathrm{~cm}),(74.3$ and $7.60 \mathrm{~cm}),(16.20$ and 16.65), (180.0 and 190.0), (15.95 and 15.43 ard.) and (3.18 and 3.38 ton) were detected by the $\mathrm{V} 2 \mathrm{xC} 1$ interaction of Bani-Swef 1 variety $\mathrm{x}$ control treatment for the above same traits in the $1^{\text {st }}$ and $2^{\text {nd }}$ seasons, respectively. On the other hand, the heaviest 1000 grains (90.48 and 53.03 gm) followed by (49.98 and 52.54 gm) were obtained by interaction of Bani-Swef 1 var. x $\mathrm{Fe}+\mathrm{Mn}+\mathrm{Zn}$ micronutrient treatment followed by 
interaction of Bani-Swef 1 var. $\mathrm{x}$ $\mathrm{Fe}+\mathrm{Zn}$ micronutrient treatment), while the thinnest 1000-grains (38.09 and $40.66 \mathrm{gm}$ ) were achieved by interaction of Giza 168 var. $x$ control treatment in the $1^{\text {st }}$ and the $2^{\text {nd }}$ seasons, respectively. Generally, the results emphasized that the Giza 168 var. (bread wheat) surpassed the Bani-Swef 1 var. (durum wheat) under different soaking grains by micronutrients either alone and/or mixture and therefore, it may be recommended that soaked grains of Giza 168 variety in micronutrients solution of $\mathrm{Fe}+\mathrm{Mn}+\mathrm{Zn}$.

\section{References:}

Allam, M.S.; M.N. Nesa; S.K. Khan; M.B. Hossain and A. Hoque (2007). Varietal differences on yield and yield contributing characters of wheat under different levels of nitrogen and planting methods. J. of App. Sci. Res., 3 (4): 1388-1392.

Arif, M.A. Ali; S. Shan; A. Javed and A. Rashid (2005). Seed priming maize for improving emergence and seedling growth. Sarhad J. Agric., 21: 239-243.

Asad, A. and R. Rafique (2000). Effect of zinc, copper, iron, manganese and boron on the yield and yield components of wheat crop in Tehsil Peshawar. J. Pakistan Boil. Sci., 3: 1615-1620.

Asgedon, H. and M. Becker (2001). Effect of seed priming with nutrient solutions on germination, seedling growth and weed competitiveness of cereals in Eritrea. In Proc. Deatscher Tropentag, Univ. Bonn and Atsaf. Margraf Publishers Bonn, WeickerSheim, 28.

Bernnan, R.F. (2001). Residual value of zinc fertilizer for production of wheat. Australian J. of Exp. Agric., 41: 541-547.
El-Habbal, M.S.; N.A. Noureldin and A.Z. Hanan (2000). Response of some wheat cultivars to transplanting. Annals Agric. Sci., Ain Shams Univ., Cairo, 45: 189-199.

El-Metwalley, I.M. and H.S. Saudy (2009). Herbicide tank-mixture efficiency on weeds and wheat productivity. Annals Agric. Sci., Moshtohor, 47 (2): 95-109.

FAO (2013). www.fao.org (C.F. Computer Research).

Ghasemi, F. and A. Ronaghi (2008). Interaction of iron with copper, zinc and manganese in a calcareous soil. J. Plant Nutr., 31: 839-848.

Gomez, K.A. and A.A. Gomez (1984). Statistical Procedures for Agricultural Research. John Wiley and Sons, Inc., New York.

Graham, R.D.; S. Senadhira; C. Beebe and I. Monasterio (1999). Breeding for micronutrient density in edible portion of staple food crops: Conventional Approaches Field Crops Res., 60: 57-80.

Hao, H.I. Wei; X.E. Yang; Y. Feng and C.Y. Wu (2007). Effects of different nitrogen fertilizer level on $\mathrm{Fe}, \mathrm{Mn}$ and $\mathrm{Zn}$ concentration in effect of $\mathrm{Fe}$ and $\mathrm{Zn}$ in wheat shoot and grain quality in rice (Oryza sativa). J. Agric. Sci., 14: 289-294.

Harb, E.Z. (1992). Effect of soaking in some growth regulators and micronutrients on growth, some chemical constituents and yield of faba bean and cotton. Plants Bulletin of Fac. Agric., Cairo Univ., 43 (1): 429-452.

Hassan, A.A. and A.B. GabAllah (2000). Response of some wheat cultivars to different levels and source of nitrogen fertilizers under new reclaimed sandy soil. 
Zagazig J. Agric. Res., 27: 1329.

Hossain, S.M.A.; A.M.A. Kamal; M.R. Islam and M.A. Mannan (2002). Effects of different levels of chemical and organic fertilizers on growth, yield and protein content of wheat. J. of Biol. Sci., 2 (5): 304-306.

Jeyabal, A. and G. Kuppuswamy (1998). Effect of seeds soaking on seedling vigour, growth and yield of rice. J. of Agron. and Crop Sci., 180 (3): 181-190.

Kaya, C.; D. Higgs and A. Button (1999). Foliar application of iron as a remedy for zinc toxic tomato plants. J. Plant Nuti., 22: 1829-1837.

Liu, Z.; H.Y. Wang; X.E. Wang; G.P. Zhang; P.O. Chen and D.J. Liu (2006). Genotypic and spike positional difference in grain phytase activity phytate, inorganic phosphorus, iron and zinc contents in wheat (Triticum aestivum L.). J. Cereal Sci., 44: 212219.

Massoud, A.M.; H.M. Salem and M.S. Awaad (2004). Effect of inoculation with Azospirillum and foliar spray of zinc and copper on wheat production and its yield components. Workshop on "Agric. Developm. in the Arab Nation", Obstacles and Solutions, Assiut, Egypt: 305315.

Noureldin, N.A.; H.A. Saudy; F. Ashmawy and H.M. Saed (2013). Grain yield response index of bread wheat cultivars as influenced by nitrogen levels. Annals Agric. Sci., 58 (2): 147152.

Pahlavan-Rad, M.R. and M. Pessarakli (2009). Response of wheat plants to zinc, iron and manganese in wheat grains. Commun.
Soil Sci., Plant-Anal, 40: 13221332.

Pearson, J.; N.Z. Rengel; C.F. Jenner and R.D. Graham (2008). Manipulation of zylem transport affects $\mathrm{Zn}$ and $\mathrm{Mn}$ transport into developing wheat grains of cultured ears. Physiol. Plant., 98: 229-234.

Saad, F.F.; S.A. Shaban and A. Said (1999). Response of some cereal crops to pre-sowing hardening treatments under saline conditions. Assiut J. of Agric. Sci., 30 (1): 43-57.

Salem, H.M. and N.Kh.B. El-Gizawy (2012). Importance of micronutrients and its application methods for improving maize (Zea mays L.) yield grown in clayey soil. American Eurasian J. Agric. \& Environ. Sci., 12 (7): 954-959.

Stoltzfus, R.J. (2001). Defining irondeficiency anemia in pubic health terms: a time for reflection 1, 2. J. Nutr., 131: 565-567.

Teama, E.A. (2001). Improving yield of maize and nitrogen use efficiency by soaking grains in some micronutrient solutions. J. Agric. Sci., 32 (2): 49-61.

Zaki, N.M.; M.A. Gomaa; F.I. Radwan; M.S. Hassanein and A.M. Wali (2012). Effect of mineral, organic and bio-fertilizer on yield, yield components and chemical composition of some wheat cultivars. J. of App. Sci. Res., 8 (1): 174-191.

Zhang, C.I.D. Mao and S. Portch (1992). Effects of zinc application with seed coating formulation (Zn-Scf) as a carrier on the growth of rice and maize international symposium on the role of sulphur, magnesium and micronutrient in balanced. Plant Nutrition, 257-261. 
تأثير نقع حبوب القمح في محاليل العناصر الصغري علي المحصول ومكوناته

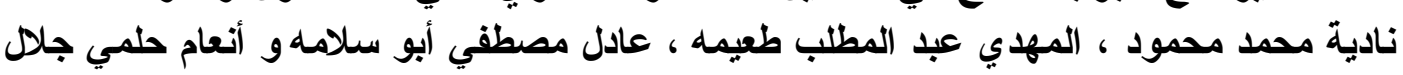

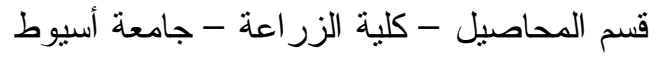

الملخص:

أجري هذا البحث بمزرعة كلية الزر اعة - جامعة أسيوط خلال موسمي الزر اعة الثتوية

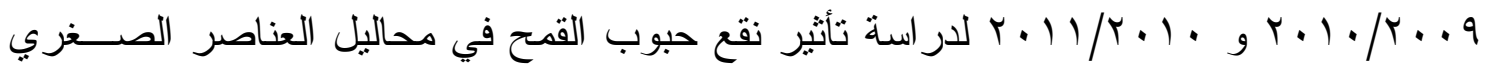
علي المحصول ومكوناته وكان التصميم المستخدم هو القطاعات الكاملة العشو ائية للقطع المنشقة لمرة و احدة في أربع مكرر ات. وضعت الأصناف جيزة 11 ا وبني سويف ا في القطع الرئيسية

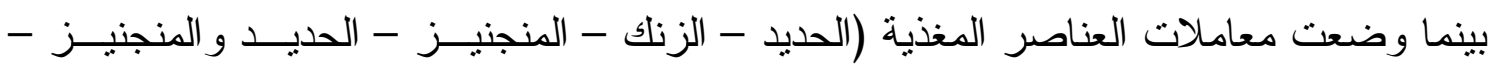
الزنك و المنجنيز - الحديد و الزنلك - الحديد و المنجنيز و الزنلك) فــي القطــع المنشــقة. وكانـــ


- تقوق الصنف جيزة 11 ا علي الصنف بني سويف ا و أعطي زيادة معنوية لطــول الســنبلة ووزن الألف حبة ومحصول القش في كلا الموسمين، كما أعطي أيضاً في الموســم الأول فقط زيادة معنوية لعدد السنيبلات/سنبلة و عدد السنابل/ مr م. - سجلت المعاملة الحديد و المنجنيز و الزنلك أعلا قيمة لكل من طول النبات، طول السـنبلة، وزن الألف حبة، عدد السنيباتلات / سنبلة، عـدد الســنابل/ج ب ، محصــول الحبـوب / فــدان ومحصول القش / فدان في كلا الموسمين.

ـ لم تتأثز جميع الصفات المدروسة معنوياً بالتفاعل بين الأصناف ومعاماتات العناصر المغذيــة في كلا الموسمين. 